Marija Kovačić, mag. oec. * Prof. dr. sc. Josip Matejaš ${ }^{* *}$

\title{
BENFORDOV ZAKON KAO KONTROLNI MEHANIZAM U RAČUNOVODSTVU I REVIZIJI
}

\author{
BENFORD'S LAW AS A CONTROL MECHANISM \\ IN ACCOUNTING AND AUDITING
}

\begin{abstract}
SAŽETAK: Benfordov zakon ili zakon prve znamenke govori o vjerojatnosti pojavljivanja pojedinih znamenki u nepristranim skupovima numeričkih podataka. Pokazalo se da se zakon odnosi na široku paletu skupova podataka: izdane račune roba i usluga, prihode i rashode, adrese, cijene, broj stanovnika, stope smrtnosti, zemljopisne podatke poput duljine rijeka, visine planina itd. Cilj ovoga rada je prikazati Benfordov zakon i mogućnosti njegove primjene te proširiti zakon na slučajeve sa specifičnim ograničenjima, a na koje se, prema postojećoj literaturi, klasični oblik zakona ne može primijeniti. Ova ideja je realizirana uvođenjem originalnog matematičkog modela. Pored nekoliko ilustrativnih primjera pokazuje se i primjena zakona na analizu vjerodostojnosti prihoda u društvu za osiguranje kao mogućeg kontrolnog mehanizma u otkrivanju nepravilnosti i prijevara.
\end{abstract}

KLJUČNE RIJEČI: vodeća znamenka, Benfordov zakon, vjerojatnost, kontrolni mehanizam.

\footnotetext{
ABSTRACT: Benford's Law or the law of the first digit tells the probability of occurrence of individual digits in an impartial set of numerical data. It has been shown that the law refers to a wide variety of data sets: issued accounts of goods and services, income and expenditures, addresses, prices, population numbers, mortality rates, geographic data such as river length, mountain height, etc. The aim of this paper is to present Benford's law and its application and to extend the law to the cases with specific limitations to which, according to the existing literature, the classical form of the law cannot be applied. This idea was realized by introducing an original mathematical model. In addition to some illustrative examples, there is also the application of the law on the analysis of the credibility of reve-

Marija Kovačić, e-mail: marija.kovacic121@gmail.com.

Prof. dr. sc. Josip Matejaš, Ekonomski fakultet Sveučilišta u Zagrebu, Trg J. F. Kennedyja 6, Zagreb, e-mail: jmatejas@efzg.hr.
} 
nues in the insurance company as a possible control mechanism in detecting irregularities and frauds.

KEY WORDS: Leading digit, Benford's law, probability, control mechanism.

\section{UVOD}

Promatra li se distribucija pojedinih znamenaka u nekom proizvoljnom skupu numeričkih podataka, najvjerojatnije neće biti uočeno neko pravilo, princip ili obrazac njihova pojavljivanja. Distribucija se doima ili slučajna ili determinirana izvorom i prirodom podataka. Međutim, uočeno je da postoji empirijski zakon (pravilo) koje govori o obrascu po kojem se znamenke pojavljuju u listi podataka, a poznat je pod nazivom Benfordov zakon. Ovaj matematički fenomen se može primijeniti u provjeri i analizama gotovo svakog skupa numeričkih podataka te se pokazao kao učinkovit alat u otkrivanju nepravilnosti i manipulacija. Na taj način postaje važan kontrolni mehanizam koji izravno može pridonijeti kvaliteti poslovanja, jer veći broj kontrolnih mehanizama osigurava veću pouzdanost i učinkovitost poslovanja. Štoviše, koristi se kao dio forenzične revizije u internim ili eksternim kontrolama u funkciji sprječavanja prijevara.

Iz toga proizlazi važnost detaljnijeg upoznavanja i razumijevanja ovoga zakona te mogućnosti njegove primjene, a čemu je posvećen ovaj rad.

Osim izvoda i prikaza samog zakona i njegove sve šire primjene koja se nalazi u suvremenoj literaturi, rad se bavi i restriktivnim slučajevima kada se zakon, prema postojećoj literaturi, ne može primijeniti. To su uglavnom slučajevi ograničenih skupova podataka s unaprijed zadanim minimumom i/ili maksimumom. Uvodeći originalni egzaktni matematički model pokazano je da se Benfordov zakon može primijeniti i u takvim slučajevima, a što predstavlja glavni doprinos rada.

Rad je strukturiran na sljedeći način. U drugom poglavlju daje se kratak pregled povijesti razvoja Benfordovog zakona te zaključci istraživača koji su se njime bavili. U trećem poglavlju prikazuje se matematički izvod i model samog zakona. Također, uvodi se proširenje i poopćenje zakona u odnosu na postojeću literaturu čime se ujedno proširuje njegova primjenjivost i korisnost. U četvrtom poglavlju se govori o područjima primjene, a u petom se Benfordov zakon primjenjuje u analizi skupa konkretnih podataka (prihoda) čime se pokazuje njegov potencijal u ulozi kontrolnog mehanizma poslovanja. Završni komentari i zaključci te smjernice daljeg istraživanja dani su u šestom poglavlju.

\section{POVIJEST BENFORDOVOG ZAKONA}

Prva objavljena istraživanja Benfordovog zakona pojavljuju se krajem 19. stoljeća (Kovačić, 2018.). U drugoj polovini prošlog stoljeća o toj je temi objavljeno više od 150 članaka dok se posljednjih 10-ak godina radovi fokusiraju na njegovu primjenu. Za otkriće Benfordovog zakona zaslužni su Simon Newcomb i Frank Albert Benford dok je Mark Nigrini uočio primjenu u otkrivanju prijevara. Ostali znanstvenici su ga dodatno razvili pri čemu treba istaknuti matematičara Hilla. Detaljan pregled znanstvenika koji su razvijali zakon je prikazan u radu Berger i Hill (2011.) i Jamain (2001.). 
Kanadski astronom i matematičar Simon Newcomb (1835. - 1909.) objavio je 1881. godine u American Journal of Mathematics prvi poznati članak o pojavi koja je kasnije nazvana Benfordov zakon. Otkrio je da u velikom setu podataka, koji mogu biti iz raznih izvora (u njegovom slučaju to su bili podatci iz područja astronomije), pojavljivanje vodeće znamenke nije za sve znamenke jednako distribuirano, kao što bi se moglo očekivati. Primijetio je da su prve stranice logaritamskih tablica odnosno stranice na kojima su brojevi koji započinju znamenkama manjih vrijednosti, istrošenije od stranica na kojima su brojevi koji započinju znamenkama većih vrijednosti. Temeljem tog zapažanja zaključio je da se brojevi koji započinju znamenkom jedan znatno češće pojavljuju od onih koji započinju znamenkom dva pa nadalje (Basrak i Varga, 2009.). Iako izgleda nelogično da znanstvenici više koriste logaritamske stranice manjih brojeva, navedeno zapažanje postaje smislenije kada se uzme u obzir da brojevi koje oni koriste nisu u potpunosti slučajni, ali niti determinirani. Naime, oni proizlaze iz nekih fizičkih konstanti ili su rezultati izvoda, matematičkih postupaka i kalkulacija. U svome istraživanju Newcomb ne daje nijedan empirijski dokaz. Dok se on bavio samo logaritamskim tablicama, 60 godina kasnije Benford je koristio puno veću bazu podataka, kako bi dokazao ovaj zakon.

Frank Albert Benford (1883. - 1948.) je bio američki inženjer elektrotehnike, fizičar i stručnjak za optička mjerenja. Najpoznatiji je po ponovnom otkriću i generalizaciji pravila koje je po njemu dobilo ime: Benfordov zakon. Nakon diplomiranja na Sveučilištu u Michiganu 1910. godine, počinje raditi u General Electricu. Godine 1938. Frank je postavio empirijske dokaze Newcombovoj tezi. Objavio je rad u kojem demonstrira da podatci iz mnogih izvora, kao što su geografski podatci, broj stanovništva, stopa smrtnosti, ulične adrese, težina molekula, razne fizičke konstante i slično, imaju tendenciju slijediti distribuciju prve značajne znamenke. S obzirom da je svoju hipotezu pokrijepio rezultatima istraživanja na 20.229 zapažanja njegov članak, za razliku od Newcombovog, biva zapažen.

Nakon Benfordovog dokaza matematičari i statističari su dugi niz godina pokušavali objasniti ovaj zakon. Objašnjavali su ga kao univerzalni prirodni zakon, ali bez empirijskih dokaza. Tako je 1961. Roger Pinkham razvio ideju da Benfordovo pravilo vrijedi i ako se podatci uvećaju ili umanje - princip nepromjenjivosti s obzirom na mjernu jedinicu ili skalu. To se uočava kod iskazivanja vrijednosti jedne valute pomoću druge, iskazivanja duljine rijeke u miljama i kilometrima i slično. Godine 1992. Mark Nigrini (Durtschi, Hillison i Pacini (2004.), str. 17.-34.) primjećuje da se Benfordov zakon može primijeniti prilikom otkrivanja prijevara u računovodstvenim podatcima. Naime, u slučaju kada čovjek smišlja prijevaru, izbor znamenaka neće biti slučajan i zato takvi namješteni brojevi neće biti u skladu s Benfordovim zakonom.

Theodore Preston Hill (1943. - ) je američki matematičar poznat po svojim istraživanjima u teoriji vjerojatnosti. Posebno se ističu njegovi radovi na Benfordovomu zakonu, teoriji optimalnog zaustavljanja i igrama s poštenom podjelom. Godine 1995. Hill pokazuje da je Benfordova distribucija empirijski dokaziv fenomen (Pečur, 2014., str. 59.-64.). Pravilno je definirao okvir za objašnjenje vjerojatnosti u Benfordovom zakonu. Promovirao je ideju da Benfordov zakon vrijedi bez obzira na bazu u kojoj su brojevi zapisani. Dokazao je da će kombinacija dviju različitih distribucija slijediti Benfordovu distribuciju neovisno jesu li one pojedinačno u skladu s njom. Primjerice, računovodstvena kategorija prihod poštovat će Benfordov zakon iako je nastala umnoškom cijene i količine, a koja svaka zasebno ne mora biti u skladu s njim. 
Mnogi znanstvenici i danas se bave istraživanjem i dokazivanjem Benfordovog zakona. Razvojem računala i programskih alata omogućena im je jednostavnija i brža obrada i primjena zakona na velikoj količini podataka. Sukladno tome, otkriveni su i novi načini njegove praktične primjene. O primjenjivosti zakona svjedoče mnogi radovi od kojih se navode neki s naglaskom na računovodstvo i reviziju.

Saville je 2006. analizirao 17 kompanija u svom radu Using Benford's Law to detect data error and fraud: An examination of companies listed on the Johannesburg Stock Exchange. Scott Carslaw 1988. godine objavljuje članak Anomalies in income numbers: evidence of goal oriented behaviour i tako prvi koristi Benfordov zakon za otkrivanje nepravilnosti u distribuciji neto dobiti (na primjeru jedne kompanije iz Novog Zelanda). Isto istraživanje proveo je Thomas 1989. (Unusual patterns in reporting earnings) koristeći Benfordov zakon za otkrivanje nepravilnosti u distribuciji neto dobiti američkih poduzeća. Kinnunen i Koskela (2001.) su proveli istraživanje nad pozicijama u financijskim izvještajima na svjetskoj razini, u razdoblju od 1995. do 1999., a rezultate objavili u Journal of International Accounting Research. Guan L. et. al. (2006.) u Auditing, integral approach to quarterly reporting, and cosmetic earnings management opisuju svoja istraživanja nad pozitivnim i negativnim kvartalnim izvješćima poduzeća iz SAD-a ispitujući utjecaj revizije na financijsko izvještavanje i učestalost manipulacija po kvartalima. U novije vrijeme ovakvih istraživanja ima sve više. Tako su Niskanen J. i Keloharju M. (2010.) istražili pojavljuju li se manipulacije u financijskim izvještajima finskih poduzeća, Fengyi L. i Sheng - Fu W. (2014.) istraživali su učestalost pojave manipulacija u razvijenim tržištima i tržištima u razvoju, Gayer D. i Drachsler C. (2014.) testirali su pojavljivanje manipulacija na pozicijama dugoročnih obveza, Stojanović i Borowiecki (2015.) proučavali su kotirane europske kompanije između 2004. i 2009. godine.

Osim stranih istraživanja postoje i hrvatski primjeri istog. $U$ radu pod nazivom Benfordov zakon i njegova primjena u forenzičkom računovodstvu Papić, Vudrić i Jerin daju dokaz Benfordovog zakona te prikazuju njegovu primjenu u analizi financijskih izvještaja 12 poduzeća kotiranih na Zagrebačkoj burzi. Također, navode i ostala ne-računovodstvena područja primjene istražena od strane drugih autora, npr. „udari gromova (Manoochehrnia et al., 2010.), potresi (Díaz et al., 2015.), nuklearne znanosti (Wells et al., 2007.), medicinske snimke (Sanches i Marques, 2006.), aktivnosti Jehovinih svjedoka (Mir, 2014.) i mnoga druga." Autor Pečur u članku Primjena Benfordovog zakona u reviziji financijskih izvještaja, uz povijesni razvoj Benfordovog zakona, prikazuje na koji način ga se može primijeniti korištenjem MS Excel-a.

Ipak, od svih navedenih za ovaj rad najvažniji je pionir primjene Benfordovog zakona u forenzičnoj reviziji, Mark Nigrini, koji u svom djelu Forensic Analytics: Methods and Techniques for Forensic Accounting Investigations, detaljno navodi metode i tehnike forenzičnog istraživanja. Navedene metode i tehnike će se primijeniti u analizi prihoda $u$ petom poglavlju.

\section{MATEMATIČKI MODEL BENFORDOVOG ZAKONA}

Benfordov zakon je posljedica logaritamske distribucije podataka.

Logaritamska funkcija inverzna je eksponencijalnoj funkciji. Zapisuje se kao

$\log _{\text {baza }}$ broj. Logaritam od broja prikazuje s kojim eksponentom treba potencirati bazu da 
se dobije broj. Dakle, može se reći da logaritam prikazuje uzrok nekog rezultata. Pri tome baza može biti bilo koji pozitivni broj različit od jedan, a najčešće se uzima 10 (dekadski logaritam), jer je to baza našeg brojevnog sustava. Vrijednost dekadskog logaritma standardno se zapisuje u normaliziranom obliku,

$$
\pm m \cdot 10^{k}, \quad 1 \leq m<10, \quad k \in\{0, \pm 1, \pm 2, \pm 3, \ldots\}
$$

gdje je $m$ mantisa a $k$ karakteristika. U tom zapisu vodeća znamenka mantise je uvijek iz skupa $\{1,2,3, \ldots, 9\}$.

Vjerojatnost da se na prvoj poziciji nekog broja nađe jedna od devet znamenki ne iznosi 1/9, što bi se uobičajeno dalo pretpostaviti. Benfordov zakon tvrdi da će približno trećina podataka počinjati znamenkom 1, dok će vjerojatnost pojavljivanja ostalih znamenaka biti to manja što je znamenka veća. Ovaj fenomen je bio poznat već duže vrijeme, ali se nisu u potpunosti mogli precizirati razlozi njegovog pojavljivanja, kao ni moguće primjene. To je jednostavno rezultat opažanja realnosti (Jamain, 2001.) koji se može objektivno matematički objasniti. Postoje različiti pristupi matematičkom izvodu Benfordovog zakona u literaturi. Ovdje se navodi originalni pristup autora generalizacijom sljedećeg primjera.

Primjer 1. Ako grad od 10.000 stanovnika raste po stopi od 2\% godišnje kada će broj stanovnika dosegnuti 20.000, 30.000, 40.000, .., 100.000?

Koristeći osnovni izraz za složeni diskretni prirast (složeni kamatni račun), $C_{n}=C_{0}(1$ $+p)^{n}$, gdje je $C_{0}$ početna vrijednost, $C_{n}$ konačna vrijednost, $p$ decimalni zapis relativnog godišnjeg prirasta (kamatne stope) a $n$ broj godina, imamo

$$
C_{n}=C_{0}(1+p)^{n} \Rightarrow n=\frac{\log d}{\log (1+p)}, d=\frac{C_{n}}{C_{0}} .
$$

U našem primjeru je $C_{0}=10.000, p=0,02$, dakle $n=n(d)=(\log d) /(\log 1,02)$. Primijetimo da vrijedi

$$
\begin{aligned}
& 1 \leq d<2 \Rightarrow 10.000 \leq C_{n}<20.000 \\
& 2 \leq d<3 \Rightarrow 20.000 \leq C_{n}<30.000 \\
& 3 \leq d<4 \Rightarrow 30.000 \leq C_{n}<40.000
\end{aligned}
$$

Dakle, cjelobrojni dio varijable $d$ određuje vodeću znamenku (vodeće znamenke) u broju stanovnika, a $n(d)$ pokazuju vremenski trenutak u kojem vodeća znamenka broja stanovnika promatranog grada prvi puta postaje $d$. Stavimo sada

$$
n_{d}=n(d+1)-n(d)=\frac{\log (d+1)-\log d}{\log (1+p)} .
$$

Očito $n_{d}$, za cjelobrojne $d$, pokazuje veličinu vremenskog intervala u kome je početna znamenka (su početne znamenke) broja stanovnika upravo $d$. Vrijednosti $n_{d}$ za $d \in\{1,2,3$, ..., 8,9\} u našem primjeru navode se u sljedećoj tablici 1. (Kovačić, 2018.). 
Tablica 1.: Frekvencije pojavljivanja prve znamenke u broju stanovnika

\begin{tabular}{|c|c|c|c|c|c|c|c|c|c|}
\hline $\boldsymbol{d}$ (početna znamenka) & 1 & 2 & 3 & 4 & 5 & 6 & 7 & 8 & 9 \\
\hline$n_{d}$ (broj godina) & 35,00 & 20,48 & 14,53 & 11,27 & 9,21 & 7,78 & 6,74 & 5,95 & 5,32 \\
\hline
\end{tabular}

Izvor: izračun autora.

Za 35 godina broj stanovnika će dosegnuti 20.000 što znači da će 35 godina početna znamenka u broju stanovnika biti broj 1. Sljedeća promjena početne znamenke dogodit će se za 20,48 godina kada će grad imati 30.000 stanovnika odnosno 14,52 godine ranije, tj. broj 1 će biti početna znamenka 14,52 godine više od broja 2. Nakon sljedećih 14,53 godina (toliko će znamenka 3 biti početna) uslijedit će ponovna promjena broja stanovnika: na 40.000 itd.

Odredimo sada relativnu frekvenciju pojavljivanja svake pojedine znamenke,

$$
r_{d}=\frac{n_{d}}{n_{1}+n_{2}+\ldots+n_{9}}, \quad d \in\{1,2, \ldots, 9\}
$$

Kako je

$$
n_{1}+n_{2}+n_{3}+\cdots+n_{8}+n_{9}=n(10)-n(1)=\frac{\log (10)-\log 1}{\log (1+p)}=\frac{1}{\log (1+p)},
$$

imamo

$$
r_{d}=\frac{\log (d+1)-\log d}{\log (1+p)}: \frac{1}{\log (1+p)}=\log (d+1)-\log d
$$

odnosno

$$
r_{d}=\log \left(\frac{d+1}{d}\right)=\log \left(1+\frac{1}{d}\right), \quad d=1,2, \ldots, 9
$$

Vidimo da dobiveni rezultat ne ovisi o zadanom prirastu (stopi) $p$. Isti rezultat dobiva se za bilo koju stopu $p$. Dobivena relativna frekvencija $r_{d}$ može se interpretirati kao vjerojatnost $P(d)$ pojavljivanja vodeće znamenke $d$ u broju stanovnika ako se broj stanovnika uzme kao nasumce odabrani podatci iz cjelokupnog razdoblja promatranja, $1 \leq d \leq 9$ (Kovačić, 2018.). Time se dobije matematički zapis Benfordovog zakona,

$$
P(d)=\log \left(1+\frac{1}{d}\right), \quad d=1,2, \ldots, 9 .
$$

Dobivene vjerojatnosti navode se u tablici 2. (Kovačić, 2018.).

Tablica 2.: Vjerojatnost pojavljivanja vodeće znamenke

\begin{tabular}{|c|c|c|c|c|c|c|c|c|c|}
\hline $\boldsymbol{d}$ & 1 & 2 & 3 & 4 & 5 & 6 & 7 & 8 & 9 \\
\hline $\boldsymbol{P}(\boldsymbol{d})(\boldsymbol{\%})$ & 30,10 & 17,61 & 12,49 & 9,69 & 7,92 & 6,69 & 5,80 & 5,12 & 4,58 \\
\hline
\end{tabular}

Izvor: izračun autora. 
Navedena vjerojatnost pojavljivanja prve znamenke vidljiva je također i iz rasporeda logaritama brojeva u logaritamskim tablicama. Iz njih se može vidjeti da je gotovo trećini brojeva prva znamenka broj jedan. Isto tako gotovo polovina brojeva ima prvu znamenku jedan ili dva. Prema ovom zakonu u skupu brojeva s bazom 10 vodeća znamenka 1 ima najveću vjerojatnost pojavljivanja odnosno 30,10\%, nakon nje slijedi znamenka 2 s vjerojatnošću od $17,61 \%$ itd., što je znamenka veća manja je vjerojatnost njenog pojavljivanja. Dakle, 9 ima najmanju vjerojatnost pojavljivanja u skupu. Može se reći da su podatci za koje vrijedi Benfordov zakon oni podatci koji rastu/padaju eksponencijalno, dakle ne oni koji rastu/padaju linearno (Berger i Hill, 2011., str. 1.-126.). Tvrdnja da se broj jedan pojavljuje u više slučajeva jer je raspon između $\log 2$ i log 1 veći nego između log 10 i log 9, biva potkrijepljena prirodnim zakonom da malim brojevima treba duže vremena da se promijene. Jednom kada mali brojevi postanu veliki zbog svojstva eksponencijalnog rasta promjena je brža, a što smo i vidjeli na primjeru o rastu stanovništva.

Benfordov zakon se može proširiti na pojavljivanje druge značajne znamenke, treće itd. Znamenke koje se mogu pojaviti na prvom mjestu su u rasponu od 1 do 9. Nula je izostavljena jer na prvom mjestu ne predstavlja značajnu znamenku. Na drugom mjestu mogu se pojaviti značajne znamenke u rasponu od 0 do 9. Nula se na drugom i svim ostalim mjestima može pojaviti kao značajna znamenka. Ako se na primjer gleda 0 kao druga znamenka tada se ona može pojaviti iza bilo koje prve znamenke $(10,20,30, \ldots, 90)$, slično znamenka $1(11,21,31, \ldots, 91)$ itd. Stoga je vjerojatnost pojavljivanja druge znamenke $d \mathrm{u}$ rasponu od 10 do 100 (10 uključeno, 100 isključeno):

$$
\begin{gathered}
p(0)=\frac{[\log 11-\log 10]+[\log 21-\log 20]+\cdots+[\log 91-\log 90]}{\log 100-\log 10}, \\
p(1)=\frac{[\log 12-\log 11]+[\log 22-\log 21]+\cdots+[\log 92-\log 91]}{\log 100-\log 10} \text { itd. }
\end{gathered}
$$

Napomenimo da se Benfordov zakon može proširiti te ima i daleko općenitije značenje koje se ne nalazi u postojećoj literaturi. Iz relacije $d=C_{n} / C_{0}$ se vidi da $d$ ne ovisi o početnoj vrijednosti $C_{0}$ već samo o relativnom odnosu $C_{n}$ i $C_{0}$. Uzme li se da je početna vrijednost $C_{0}=100 \%$ imamo:

$$
\begin{gathered}
\left.1 \leq d<2 \Rightarrow 100 \% \leq C_{n}<200 \% \text { (vodeća znamenka } 1\right) \\
\left.2 \leq d<3 \Rightarrow 200 \% \leq C_{n}<300 \% \text { (vodeća znamenka } 2\right) \\
3 \leq d<4 \Rightarrow 300 \% \leq C_{n}<400 \%(\text { vodeća znamenka } 3) \text { itd. }
\end{gathered}
$$

To znači da Benfordov zakon opisuje trajanje vodeće znamenke u postotnoj (relativnoj) vrijednosti neke veličine koja se mijenja uz konstantni prirast - kamatnu stopu (složeni ili neprekidni kamatni račun - račun prirasta). Dakle, ako u našem primjeru grad ima $20.000=100 \%$ stanovnika tada u apsolutnom iznosu nema vodeće znamenke 1, ali u relativnom imamo $(100-200 \%$, tj. 20.000 - 40.000 stanovnika) pa se zakon može primijeniti. Upravo ta neovisnost o početnoj vrijednosti kao i o stopi prirasta pokazuje njegovu univerzalnost. 
Nadalje, u navedenoj analizi ograničili smo se samo na cjelobrojne vrijednosti varijable $d$. Zato se u definiciji za $n_{d}$ pojavljuje $d$ i $d+1$ (njegov sljedbenik). Općenitije, ako se promatraju bilo koje (realne) vrijednosti $d^{\prime}>d$, tada umjesto $n_{d}$ imamo

$$
n_{d d^{\prime}}=n\left(d^{\prime}\right)-n(d)=\frac{\log d^{\prime}-\log d}{\log (1+p)} .
$$

Primjenu ilustriramo na sljedećem primjeru.

Primjer 2. Ako neka živa jedinka ili populacija (biljna, životinjska ili ljudska) raste po stopi od $15 \%$ godišnje u kojem razdoblju će imati vrijednost 150 - 160\% početne?

Imamo $d^{\prime}=1,6 ; d=1,5 ; p=0,15$ pa je

$$
\begin{gathered}
n(1,5)=\frac{\log 1,5}{\log 1,15}=2,90111 \\
n_{1,5 ; 1,6}=\frac{\log 1,6-\log 1,5}{\log 1,15}=0,46177 .
\end{gathered}
$$

Dakle, $150 \%$ početne vrijednosti doseći će za 2,90111 godine $=2$ godine 10 mjeseci 24 dana te će u rasponu $150-160 \%$ ostati sljedećih 0,46177 godina $=5$ mjeseci 16 dana (Kovačić, 2018.).

Napomenimo još da se Benfordov zakon može primijeniti i na brojevni sustav u bilo kojoj bazi (osim baza 10). Ako se radi o bazi $b$ tada Benfordov zakon glasi

$$
P(d)=\log _{b}\left(1+\frac{1}{d}\right), \quad d=1,2, \ldots, b-1 .
$$

Kako je općenito prijelaz s logaritamske baze na dan izrazom $\log _{y} z=\left(\log _{x} z\right) /\left(\log _{x} y\right)$ navedena relacija se može zapisati u standardnim logaritamskim bazama $10(\log )$ ili $e(\ln )$,

$$
P(d)=\log _{b}\left(1+\frac{1}{d}\right)=\frac{1}{\log b} \log \left(1+\frac{1}{d}\right)=\frac{1}{\ln b} \ln \left(1+\frac{1}{d}\right) .
$$

Navedene formule mogu se koristiti za analizu distribucije podataka reprezentiranih $\mathrm{u}$ memoriji računala (binarni, oktalni, heksadecimalni brojevni sustav) (Kovačić, 2018.). Tako na primjer za bazu $b=2$ imamo

$$
P(1)=\log _{2}\left(1+\frac{1}{1}\right)=\log _{2} 2=1=100 \%,
$$

što znači da je u binarnom brojevnom sustavu vodeća znamenka svakog broja 1.

Za oktalni sustav $(b=8)$ vjerojatnosti pojavljivanja vodećih znamenki dane su u tablici 3 .

Tablica 3.: Vjerojatnost pojavljivanja vodeće znamenke u oktalnom sustavu

\begin{tabular}{|c|c|c|c|c|c|c|c|}
\hline$d$ & 1 & 2 & 3 & 4 & 5 & 6 & 7 \\
\hline $\boldsymbol{P}(\boldsymbol{d}) \%$ & 33,33 & 19,50 & 13,83 & 10,73 & 8,77 & 7,41 & 6,42 \\
\hline
\end{tabular}

Izvor: izračun autora. 
Temeljem svega navedenog vidi se da je Benfordov zakon ustvari vjerojatnost na logaritamskoj skali. Zbog toga se može poopćiti na bilo koji skup numeričkih podataka. U tom slučaju za neki njegov podskup (koji se analizira) određuje se relativna frekvencija u odnosu na cijeli skup na logaritamskoj skali (Kovačić, 2018.).

Primjer 3. Odredimo vjerojatnost pojavljivanja vodećih znamenaka, u skladu s Benfordovim zakonom, kod brojeva iz intervala [2500, 5000).

Kako je logaritamski raspon zadanog intervala

$$
\log 5000-\log 2500=\log 2,
$$

imamo

$$
\begin{aligned}
& p(2)=\frac{\log 3000-\log 2500}{\log 2}=0,2630=26,30 \% ; \\
& p(3)=\frac{\log 4000-\log 3000}{\log 2}=0,4150=41,50 \% ; \\
& p(4)=\frac{\log 5000-\log 4000}{\log 2}=0,3219=32,19 \% .
\end{aligned}
$$

Time je pokazano kako se uklanjaju ograničenja (zadana minimalna ili maksimalna vrijednost odnosno interval u kome se podatci nalaze) uz koja, prema postojećoj literaturi, klasični oblik Benfordovog zakona nije primjenljiv.

\section{PODRUČJA PRIMJENLJIVOSTI BENFORDOVOG ZAKONA}

U ranim godinama proučavanja znanstvenici nisu vidjeli praktičnu primjenu Benfordovog zakona. Primjena se počinje nazirati tek 70-ih godina 20. stoljeća s pojavom računala dok se puna primjena otkriva u 90-ima. Benfordov zakon se može primijeniti na skupove iz različitih područja: izdane račune roba i usluga, prihode i rashode, adrese, cijene, broj stanovnika, stope smrtnosti, zemljopisne podatke poput duljine rijeka, visine planina itd. Neka od novijih područja primjene su: dizajn računala, modeliranje i otkrivanje prijevara (Jamain, 2001.).

U početcima razvoja računala logaritmi su korišteni za optimiziranje pohrane podataka i brzine obrade. Kod dizajna računala ili pisanja rutina važno je razmotriti očekivane inpute (operande). Benford se nametnuo kao odličan prediktor inputa, no zbog brzog razvoja računalne tehnologije, ovakva optimizacija više nije potrebna.

Kod modeliranja podataka i projekcija, npr. broja stanovnika, financijskih indeksa i slično, pod pretpostavkom Benford-in, Benford-out, tj. ako set vrijednosti slijedi Benfordov zakon, tada i modeli koji imaju cilj predvidjeti takve buduće vrijednosti trebali bi slijediti Benfordov zakon.

Od početka otkrića zakon se upotrebljava u otkrivanju prijevara, a u kombinaciji s korištenjem alata za otkrivanje znanja u bazama podataka, ekspertnih sustava i drugih. 
Pretpostavka je da manipulirani, prijevarni podatci ne prate Benfordov zakon, a ne-manipulirani ga prate. Profesor Nigrini 1995. godine prvi primjenjuje Benfordov zakon u ovom području i pokazuje kako se može koristiti kao pokazatelj u financijskim manipulacijama, npr. uspoređujući podudarnost uplata, isplata, iznose osiguranja s ovim zakonom. U ime suda u New York-u izrađuje računalni program s implementiranim Benfordovim značajkama za provjeru vjerodostojnosti objavljenih računovodstvenih podataka. Tom prilikom sedam kompanija je optuženo za prijevaru pa se odtada Benfordov zakon koristi i u računovodstvenoj praksi.

S kvantitativnog aspekta Benfordov zakon se, prema postojećoj literaturi, može primijeniti na gotovo sve tipove numeričkih podataka. Teškoće mogu nastati ako su podaci unaprijed ograničeni donjom ili gornjom granicom. U prethodnom poglavlju prikazana je matematička konstrukcija koja omogućava primjenu zakona i u takvim slučajevima.

Ostaje pitanje na koje se skupove podataka, s obzirom na njihovo podrijetlo, Benfordov zakon (ne) može primijeniti. U kojoj mjeri (i na koji način) su to slučajni odnosno determinirani podaci? Cjelovit odgovor na ovo pitanje još uvijek je otvoren problem. Otkrivanje principa po kojima su takvi skupovi generirani kao i njihova kategorizacija može biti zanimljivo područje za buduća istraživanja. Tim više što se takvi skupovi pojavljuju u svim područjima ljudskog djelovanja, počevši od kemije, biologije, astronomije, zemljopisa pa sve do širokog područja ekonomije. Kako živimo u informacijskom dobu, svakodnevno eksponirani mnogobrojnim informacijama i podacima, vjerujemo da će Benfordov zakon tek u budućnosti dobiti svoje pravo mjesto i značaj.

\section{KONTROLA RAČUNOVODSTVENIH PODATAKA NA PRIMJERU PRIHODA}

U nastavku se pokazuje primjena ovoga zakona u analizi vjerodostojnosti konkretnih podataka - prihoda, što je samo jedan od dokaza njegove primjene kao kontrolnog mehanizma, osobito u forenzičnoj reviziji.

Radi boljeg razumijevanja ovoga poglavlja pojasnimo pojmove: prijevara, prijevarno financijsko izvještavanje, a u nastavku i pojam prihoda. Prijevara je čin primanja mita, zloupotrebe imovine poduzeća ili prijevarnog financijskog izvještavanja. Prijevarno financijsko izvještavanje obuhvaća namjerna pogrešna prikazivanja, propuste iznosa ili objava u financijskim izvještajima kako bi se zavelo korisnike financijskih izvještaja. Može se ostvariti manipulacijom, falsificiranjem ili izmjenom računovodstvenih evidencija ili dokumentacije, pogrešnim prikazivanjem, namjernim propustima, krivom primjenom računovodstvenih principa. Prijevare s prihodima je moguće izvršiti lažiranjem dokumentacije, simuliranjem događaja koji se nisu trebali dogoditi, zloupotrebom računovodstvenih pravila (Belak, 2017.).

Ovdje je fokus primjene na usporedbi vrijednosti prihoda iz financijskih izvještaja osiguravajućeg društva $\mathrm{X}$ d.d. s očekivanim vrijednostima prema Benfordovom zakonu te procjena vjerodostojnosti primjenom četiri statistička testa.

Za ovu analizu podatci su prikupljeni iz javno objavljenih financijskih izvještaja, s mrežnih stranica poduzeća i Zagrebačke burze. Preciznije, korišteni su izvještaji: Tromjesečni financijski izvještaj društva za osiguranje TFI-OSIG (nekonsolidirani kvartalni izvještaji za 2009. godinu) i Tromjesečni financijski izvještaj društva za osiguranje odnosno 
društva za reosiguranje TFI-OSIG/RE (nekonsolidirani kvartalni izvještaji od 2010. do 2017. godine), što ukupno obuhvaća 36 kvartala (Hrvatska agencija za nadzor financijskih usluga, 2016.). Broj podataka je 1.015 stavaka prihoda.

Prihod predstavlja povećanje ekonomskih koristi tijekom obračunskog razdoblja u obliku priljeva ili povećanja imovine ili smanjenja obveza, kada ti priljevi imaju za posljedicu povećanje kapitala, osim povećanja kapitala koje se odnosi na unose od strane sudionika u kapitalu (Belak, V. et al., 2014.). Pojam prihoda u djelatnosti osiguranja definiran je Međunarodnim standardom financijskog izvještavanja 4 - Ugovori o osiguranju, te drugim standardima koji obrađuju ostale prihode povezane s financijskom imovinom, nekretninama i drugim osnovama za ostvarivanje prihoda. Svaka kategorija prihoda ima svoja posebna obilježja, npr., zaračunate bruto premije životnih osiguranja se prikazuju kao prihod u trenutku naplate od kupca i u iznosu koji je naplaćen (gotovinska osnova) dok se zaračunate bruto premije neživotnih osiguranja prikazuju kao prihod po sklopljenom ugovoru (ugovorna osnova).

Imajući u vidu da je prihod u osiguravajućem društvu varijabla pod utjecajem mnogih čimbenika, primjećuje se da je kao takva pogodna za analizu Benfordovim zakonom.

Preporučeni minimalni opseg statističkog skupa je 1.000 podataka jer prema teorijskoj pretpostavci zakona veći broj podataka daje vjerodostojnije rezultate, a relativno mali broj jedinica predstavlja ograničenje. Dodatno ograničenje su pozitivne i negativne vrijednosti u populaciji jer negativne stavke prihoda imaju tendenciju padati, a pozitivne stavke prihoda rasti - kako bi u konačnici došlo do većeg prihoda.

Dvije karakteristike podataka moraju biti zadovoljene da skup podataka prati Benforodovu distribuciju: medijan mora biti manji od aritmetičke sredine, a asimetrija mora biti pozitivna (Nigrini, 2011.). U tablici 4., u stupcu Uvjet za Benfordov zakon, vidljivo je da su navedeni uvjeti, koji se odnose na aritmetičku sredinu i asimetriju, ispunjeni kao i da je zadovoljen preporučeni minimalni opseg statističkog skupa podataka uzetih za analizu.

Tablica 4.: Deskriptivna statistika

\begin{tabular}{|l|r|l|}
\hline & Svi prihodi & Uvjet za Benfordov zakon \\
\hline Mean & 24.242 .302 & $>$ medijana \\
\hline Standard Error & 3.491 .025 & \\
\hline Median & 699.917 & $<$ aritmetičke sredine \\
\hline Mode & 20.000 & \\
\hline Standard Deviation & 111.220 .793 & \\
\hline Kurtosis & 25 & \\
\hline Skewness & 5 & $>0$ \\
\hline Range & 1.197 .914 .903 & \\
\hline Minimum & -302.673 .092 & \\
\hline Maximum & 895.241 .811 & \\
\hline Sum & 24.605 .936 .837 & \\
\hline Count & 1.015 & $>1.000$ \\
\hline
\end{tabular}

Izvor: izrada autora (korištenjem paketa Deskriptivne statistike u tabličnom kalkulatoru).

Cilj analize je empirijski istražiti postoje li nepravilnosti odnosno odstupanja u iznosima prihoda u društvu za osiguranje koja mogu ukazivati na manipulacije pa je postavljena 
sljedeća hipoteza: Vjerojatnost pojavljivanja znamenki na određenim pozicijama u brojčanim iznosima prihoda iz promatranog uzorka nije u skladu s Benfordovom distribucijom što implicira potrebu za dodatnom detaljnijom analizom šireg skupa podataka radi utvrđivanja razloga neusklađenosti ili eventualnih nepravilnosti.

Iz seta podataka analizirana je distribucija prve znamenke i prvih dviju znamenki prihoda u financijskim izvještajima. Korištenjem tabličnog kalkulatora - funkcijom ABS pretvorene su sve vrijednosti u apsolutne vrijednosti, zatim je funkcijom LEFT izdvojena prva znamenka. ${ }^{1} \mathrm{Na}$ taj način izdvojene su prve znamenke kategorije prihoda. Nakon identificirane prve znamenke, sljedeći korak je izdvajanje i analiza prve dvije znamenke. Dobiveni podatci su pobrojani (korištenjem zaokretnih tablica) i grafički prikazani usporedno s Benfordovom distribucijom udjela prve i prvih dviju znamenaka, što se može vidjeti na grafikonu 1. i grafikonu 2. (Kovačić, 2018.).

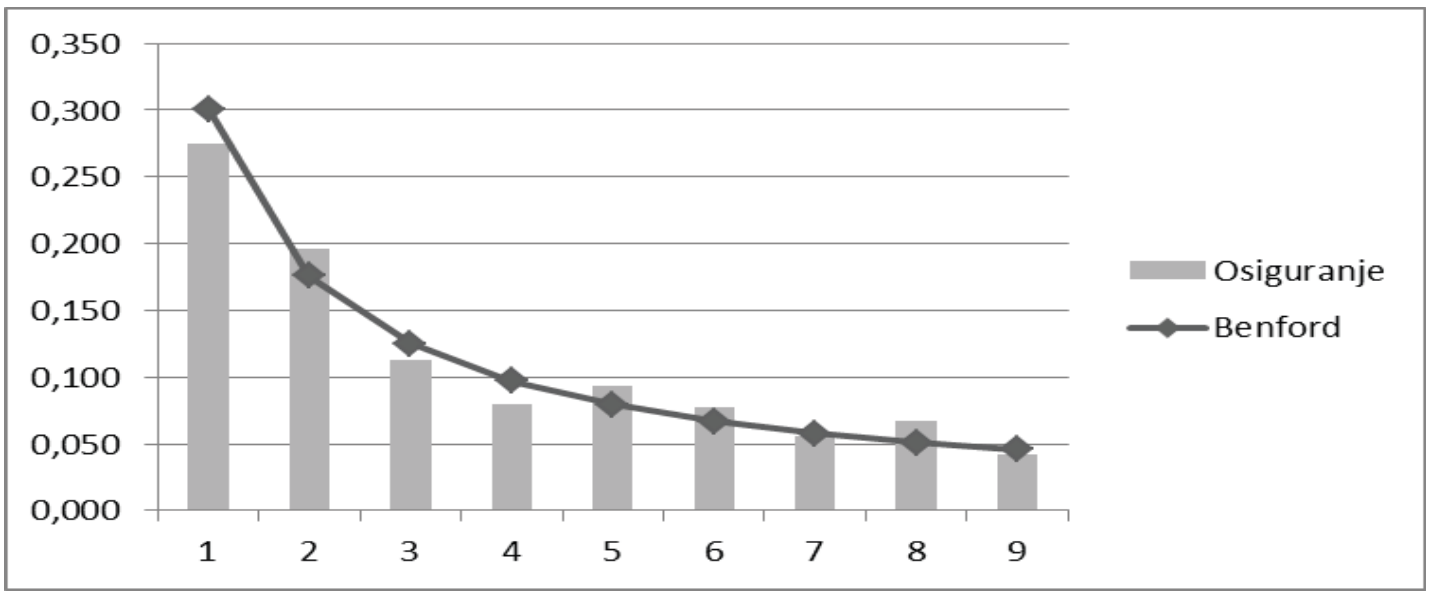

Grafikon 1.: Frekvencija prve znamenke prihoda osiguravajućeg društva i Benfordovog zakona Izvor: izrada autora.

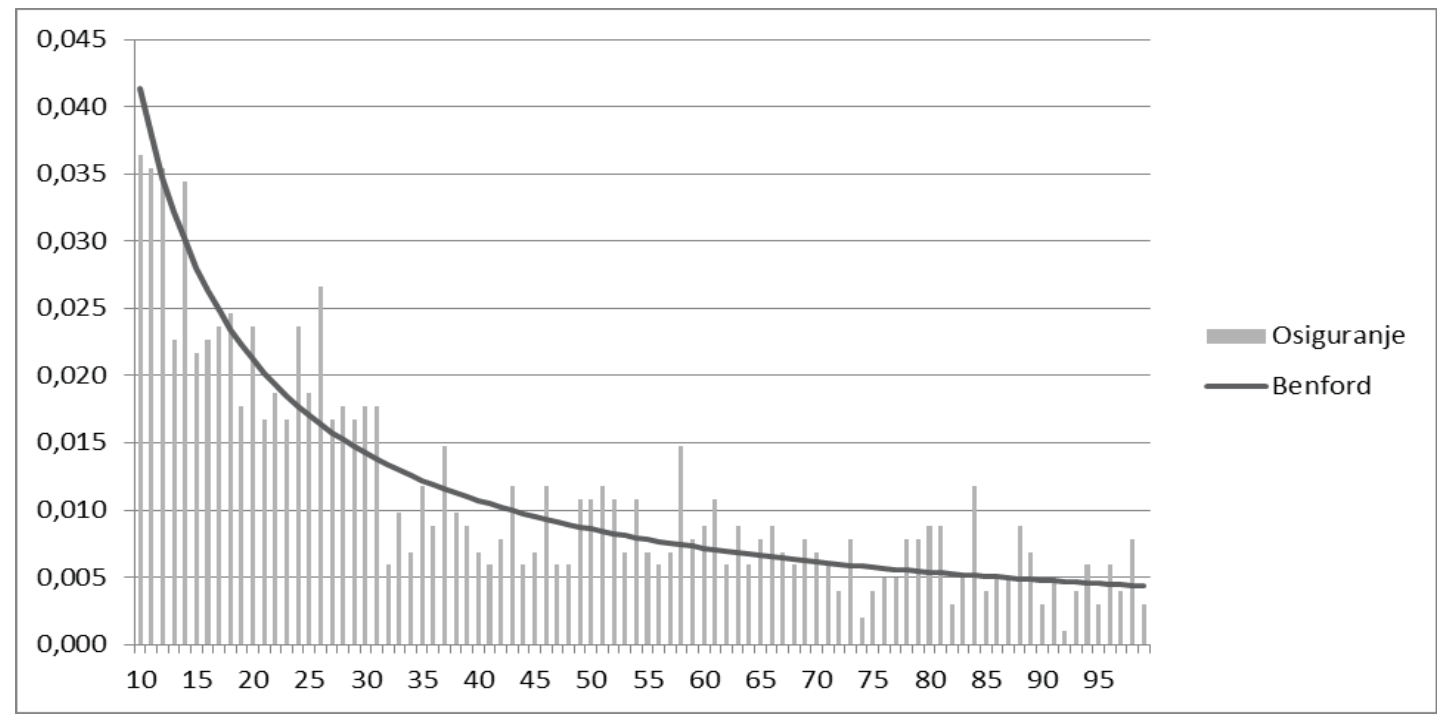

Grafikon 2.: Frekvencija prve dvije znamenke prihoda osiguravajućeg društva i Benfordovog zakona Izvor: izrada autora.

Sve vrijednosti u rasponu od -1 do 1 su izuzete iz analize. 
Nakon što se u pokaznom primjeru analiziraju podatci i napravi usporedba s očekivanom distribucijom, potrebno je ocijeniti jesu li odstupanja značajna. Razina odstupanja stvarnih od vrijednosti po Benfordovom pravilu se može mjeriti sljedećim statističkim testovima (Papić, Vudrić i Jerin, 2017.): Z testom, hi-kvadrat testom, Kolmogorov-Smirnovljev testom, prosječnim apsolutnim odstupanjem (MAD).

Višestruki statistički testovi odnosno metode analize odstupanja, koriste se kako bi se smanjila pogreška u donošenju odluke o postojanju prijevarnih podataka. U tablici 5. se navode preporučene granične vrijednosti (Nigrini, 2011.), ispod/iznad kojih će se smatrati da odstupanja nisu/jesu značajna.

Tablica 5.: Granične vrijednosti testova

\begin{tabular}{|l|c|c|}
\hline Test / Znamenka & Prva znamenka & Prva i druga znamenka \\
\hline MAD & $<0,0015$ & $<0,0022$ \\
\hline Z test & $<1,96$ & $<1,96$ \\
\hline Hi kvadrat & $<15,51$ & $<112,02$ \\
\hline K-S & $\begin{array}{c}\text { kumulativno } \\
\text { odstupanje }<0,043\end{array}$ \\
\hline
\end{tabular}

Izvor: izrada autora.

Distribucija znamenaka neke distribucije stvarnih podataka neće nikada biti potpuno jednaka Benfordovoj. Zato se kroz izračun i analizu ostupanja, kako je prikazano u nastav$\mathrm{ku}$ te nakon pojedinačnih interpretacija rezultata donose sumarni zaključci da li ocjena testa: potvrđuje, ne potvrđuje ili je neutralna u usporedbi s postavljenom hipotezom.

Izračun odstupanja za prvu znamenku pokazuje sljedeće rezultate (vidjeti Dodatak 1.):

- prosječno apsolutno odstupanje (MAD) iznosi 0,014 i nalazi se iznad granice od 0,0015 te zahtijeva posebnu pozornost zbog sumnje u prijevarne podatke

- Z test za znamenku 8 u podatcima svih prihoda iznosi 2,22 i ta je vrijednost iznad granične vrijednosti od 1,96 pa se može zaključiti da je znamenka 8 pod povećanom sumnjom

- hi kvadrat svih prihoda iznosi 18,72 (0,018 x 1.015 jedinica) što je iznad granične vrijednosti od 15,51 i ukazuje na nepravilnosti u podatcima

- Kolmogorov-Smirnovljev test ne pokazuje kumulirana odstupanja veća od granice od 0,043 .

Zaključno, odstupanja potvrđuju neusklađenost s Benfordovom distribucijom prema MAD i hi kvadrat testovima. Prema $\mathrm{Z}$ testu potvrđena je hipoteza za znamenku 8 za koju postoji sumnja, a za ostale nije potvrđena. Kolmogorov-Smirnovljev test ne potvrđuje hipotezu.

Izračun odstupanja za prve dvije znamenke pokazuje sljedeće rezultate (vidjeti Dodatak 2.):

- prosječno apsolutno odstupanje (MAD) iznosi 0,003 i predstavlja veliko odstupanje u odnosu na postavljenu graničnu vrijednost od 0,0022

- kombinacije znamenki 26, 58 i 84 u populaciji svih prihoda prema Z testu imaju vrijednosti iznad 1,96 - što ih svrstava u stavke koje treba posebno razmotriti 
- hi kvadrat svih prihoda iznosi 90,92 (0,090 x 1.015 jedinica) što je ispod granične vrijednosti od 112,02

- Kolmogorov-Smirnovljev test ne pokazuje kumulirana odstupanja veća od granice od 0,043 za sve prihode.

Zaključno, postoje nepravilnosti prema MAD odstupanju (ocjena testa potvrđuje hipotezu), određene kombinacije premašuju 1,96 graničnu vrijednost prema $Z$ testu (potvrđuju hipotezu), a hi kvadrat ne ukazuje na nepravilnosti (ne potvrđuje hipotezu). Kolmogorov-Smirnovljev test ne ukazuje na nepravilnosti (Kovačić, 2018.).

Provedenom analizom utvrđeno je da su odstupanja distribucije znamenaka od Benfordove distribucije značajna i za prvu i za prve dvije znamenke. Ovakvi rezultati motiviraju da se podatci detaljnije analiziraju kako bi se razumjeli uzroci odstupanja, primjerice ukazuju na potrebu za analizom većeg broja ili svih podataka (npr. 5.000 i više) odnosno detaljnijim praćenjem poslovanja.

Odstupanja ne ukazuju odmah na sigurno postojanje prijevare, već mogu ukazivati na specifičnosti (atipičnosti) tržišta - predmeta osiguranja ili ekonomske situacije - klijenta i sl. Dakle, u svakom slučaju potrebu za daljnjom analizom radi stjecanja dubljeg uvida u strukturu cjelokupne situacije kako bi se otkrilo što je uzrok i olakšali daljnji postupci i prosudbe. U konačnici to je dobro i za poduzeće u svrhu planiranja boljeg budućeg poslovanja.

\section{ZAKLJUČAK}

U ovom su radu prezentirana osnovna saznanja vezana uz teorijski i praktični aspekt te primjenu Benfordovog zakona. Budući da predstavlja jedan od značajnijih alata u analizi i indiciranju nepravilnosti u skupovima numeričkih podataka, opravdana je motivacija za pisanjem o ovoj temi.

Benfordov zakon je jednostavno, iako na prvi pogled nelogično pravilo. Posljedica je logaritamske distribucije podataka. U osnovi pokazuje da vjerojatnost pojavljivanja neke znamenke u skupu različitih brojeva nije za svaku znamenku ista. Tako će približno trećina podataka počinjati znamenkom 1, dok će vjerojatnost pojavljivanja ostalih znamenaka biti to manja što je vrijednost znamenke veća. Koristeći osnovni izraz za složeni diskretni prirast: $C_{n}=C_{0}(1+p)^{n}$, dolazimo do matematičkog zapisa Benfordovog zakona, $P(d)=\log \left(1+\frac{1}{d}\right), d=1,2, \ldots, 9$. Ovaj zakon primjenljiv je na gotovo sve vrste skupova numeričkih podataka iz različitih izvora. U radu je pokazano kako se zakon može proširiti i na restriktivne skupove (sa zadanom donjom i/ili gornjom granicom), a što je u postojećoj literaturi evidentirano kao ograničenje u njegovoj primjeni. To je ujedno i jedan od glavnih doprinosa ovoga rada.

Analizom distribucije prve znamenke i prve dvije znamenke prihoda iz financijskih izvještaja osiguravajućeg društva u usporedbi s Benfordovom distribucijom praktično je prikazana njegova primjena. Za ovo empirijsko istraživanje na 1.015 stavaka prihoda postavljena je hipoteza koja se pokušala dokazati ili opovrgnuti: Vjerojatnost pojavljivanja znamenki na određenim pozicijama u brojčanim iznosima prihoda iz promatranog uzorka nije u skladu s Benfordovom distribucijom što implicira potrebu za dodatnom detaljnijom analizom šireg skupa podataka radi utvrđivanja razloga neusklađenosti ili eventualnih nepravilnosti. 
Rezultati empirijskog istraživanja prihoda osiguravajućeg društva su pokazali određena odstupanja od Benfordovog zakona, što usmjerava istraživača da veću pozornost posveti takvim anomalijama i pristupi detaljnijim izvještajima.

Benfordov zakon pomaže forenzičnom revizoru otkriti prijevaru odnosno nepravilnosti uzrokovane manipulacijom podatcima te tako može postati standardni kontrolni alat inicijalne provjere. Njime se ne može direktno (eksplicitno) otkriti prijevaru, ali se može potaknuti na preispitivanje vjerodostojnosti, točnosti ili potpunosti podataka. Primjena ovoga zakona je višestruka te će svakako će biti zanimljivo pratiti njegov daljnji razvoj i mogućnosti primjene. Upravo područja primjene otvaraju mnogobrojne smjernice za dalje istraživanje.

\section{LITERATURA}

1. Basrak, B. i Varga, I. (2009.) Benfordov zakon. Math.e [online], 23. Dostupno na: http://e.math.hr/vol23/Basrak [18. prosinca 2017.].

2. Belak, V. (2017.) Lažiranje financijskih izvještaja, prijevare i računovodstvena forenzika: 60 slučajeva iz prakse. Zagreb: Belak excellens d.o.o.

3. Belak, V. et al. (2014.) Knjiženje poslovnih događaja redoslijedom RRiF-ovog računskog plana za poduzetnike: Prihodi. U: Guzid, Š., ur., Računovodstvo poduzetnika: s primjerima knjiženja. Zagreb: RRiF plus, str. 945.

4. Berger, A. i Hill, T. P. (2011.) A basic theory of Benford's Law. Probability Surveys [online], 8, str. 1-126. Dostupno na: https://projecteuclid.org/euclid.ps/1311860830 [18. prosinca 2017.].

5. Carslaw, C. (1988.) Anomalies in income numbers: evidence of goal oriented behaviour, The Accounting review [online], 63(2), str. 321-327. Dostupno na: https:// www.jstor.org/stable/248109?seq=1\#page_scan_tab_contents [19. listopada 2018.].

6. Durtschi, C., Hillison, W. i Pacini, C. (2004.) The Effective Use of Benford's Law to Assist in Detecting Fraud in Accounting Data. Journal of Forensic Accounting [online], V, str. 17-34. Dostupno na: https://www.agacgfm.org/aga/fraudtoolkit/documents/ benfordslaw.pdf [18. prosinca 2017.].

7. Guan, L. et. al. (2006.) Auditing, integral approach to quarterly reporting, and cosmetic earnings management. Managerial Auditing Journal [online], 21(6), str. 569-581. Dostupno na: https://www.researchgate.net/publication/235261807_Auditing_Integral_Approach_to_Quarterly_Reporting_and_Cosmetic_Earnings_Management [19. listopada 2018.].

8. Hrvatska agencija za nadzor financijskih usluga (2016.). Tehničke upute i obrasci [online]. Zagreb: Hrvatska agencija za nadzor financijskih usluga. Dostupno na: https:// www.hanfa.hr/getfile/6664/Obrazac\%20TFI-OSIG-RE\%20(Dostaviti\%20u \%20 XLS\%20formatu).xls [2. svibnja 2018.].

9. Jamain, A. (2001.). Benford's Law [online]. Imperial College of London \& ENSIMAG. Dostupno na: http://wwwf.imperial.ac.uk/ nadams/classificationgroup/Benfords-Law.pdf [18. prosinca 2017.].

10. Kinnunen, J. i Koskela, M. (2003.): Who is Miss World in cosmetic earnings management? A cross-national comparison of small upward rounding of net income numbers among eighteen countries. Journal of International Accounting Research 
[online], 2(2), str. 39-68. Dostupno na: https://www.researchgate.net/publication/228306519_Who_Is_Miss_World_in_CosmeticEarnings_Management_-_A_ Cross-National_Comparison_of_Small_Upward_Rounding_of_Net_Income_Numbers_AmongEighteen_Countries [19. listopada 2018.].

11. Kovačić, M. (2018.) Primjena Benfordovog zakona u forenzičnoj reviziji. Diplomski rad. Ekonomski fakultet Sveučilišta u Zagrebu.

12. Međunarodni revizijski standardi [online]. Međunarodna federacija računovođa (IFAC). Dostupno na: http://www.revizorska-komora.hr/pdf/MRevS/1_KB-zaCIP-124.pdf [18. prosinca 2017.].

13. Nigrini, Mark J. (2011.) Forensic Analytics: Methods and Techniques for Forensic Accounting Investigations. Hoboken: J. Wiley \& Sons, cop.

14. Papić, M., Vudrić, N. i Jerin, K. (2017.) Benfordov zakon i njegova primjena u forenzičnom računovodstvu. Zbornik sveučilišta Libertas [online], 1-2 (1-2). Dostupno na: http://hrcak.srce.hr/190860 [19. listopada 2018.].

15. Pečur, I. (2014.) Primjena Benfordovog zakona u reviziji financijskih izvještaja. Računovodstvo i financije [online], izdanje 12/2014., str. 59-64. Dostupno na: http://rif. hr/e-izdanje/rif-12-2014/assets/basic-html/page67.html [19. listopada 2018.].

16. Saville, A. (2006.) Using Benford's Law to detect data error and fraud: An examination of companies listed on the Johannesburg Stock Exchange. South African Journal of Economic and Management Sciences [online], 9(3), str. 341-354. Dostupno na: https://www.researchgate.net/publication/267224545_Using_Benford\%27s_Law_to_ detect_data_error_and_fraud_An_examination_of_companies_listed_on_the_Johannesburg_Stock_Exchange [19. listopada 2018.].

17. Thomas, K. (1989.) Unusual patterns in reporting earnings. The Accounting Review [online], 64(4), str. 737-787. Dostupno na: https://www.jstor.org/stable/pdf/247861. pdf?seq=1\#page_scan_tab_contents [19. listopada 2018.]. 
DODATAK 1.: Izračun odstupanja za prvu znamenku

\begin{tabular}{|c|c|c|c|c|c|c|}
\hline & Benford & Svi prihodi & \multicolumn{4}{|c|}{ Svi prihodi } \\
\hline$\#$ & Prva & Prva & MAD & Z test & Hi kvadrat & K-S \\
\hline $\mathbf{1}$ & 0,301 & 0,275 & 0,026 & 1,782 & 0,002 & 0,026 \\
\hline $\mathbf{2}$ & 0,176 & 0,196 & 0,020 & 1,629 & 0,002 & 0,006 \\
\hline $\mathbf{3}$ & 0,125 & 0,112 & 0,013 & 1,169 & 0,001 & 0,019 \\
\hline $\mathbf{4}$ & 0,097 & 0,080 & 0,017 & 1,789 & 0,003 & 0,036 \\
\hline $\mathbf{5}$ & 0,079 & 0,094 & 0,014 & 1,643 & 0,003 & 0,021 \\
\hline $\mathbf{6}$ & 0,067 & 0,078 & 0,011 & 1,324 & 0,002 & 0,011 \\
\hline $\mathbf{7}$ & 0,058 & 0,056 & 0,002 & 0,183 & 0,000 & 0,012 \\
\hline $\mathbf{8}$ & 0,051 & 0,067 & 0,016 & 2,220 & 0,005 & 0,003 \\
\hline $\mathbf{9}$ & 0,046 & 0,042 & 0,003 & 0,443 & 0,000 & 0,000 \\
\hline & & & 0,014 & & 0,018 & 0,043 \\
\hline
\end{tabular}

Izvor: izrada autora.

DODATAK 2.: Izračun odstupanja za prve dvije znamenke

\begin{tabular}{|c|c|c|c|c|c|c|}
\hline & Benford & Svi prihodi & \multicolumn{4}{|c|}{ Svi prihodi } \\
\hline$\#$ & Prva i druga & Prva i druga & MAD & Z test & Hi kvadrat & K-S \\
\hline $\mathbf{1 0}$ & 0,041 & 0,036 & 0,005 & 0,711 & 0,001 & 0,005 \\
\hline $\mathbf{1 1}$ & 0,038 & 0,035 & 0,002 & 0,305 & 0,000 & 0,007 \\
\hline $\mathbf{1 2}$ & 0,035 & 0,035 & 0,001 & 0,037 & 0,000 & 0,007 \\
\hline $\mathbf{1 3}$ & 0,032 & 0,023 & 0,010 & 1,630 & 0,003 & 0,016 \\
\hline $\mathbf{1 4}$ & 0,030 & 0,034 & 0,005 & 0,753 & 0,001 & 0,012 \\
\hline $\mathbf{1 5}$ & 0,028 & 0,022 & 0,006 & 1,131 & 0,001 & 0,018 \\
\hline $\mathbf{1 6}$ & 0,026 & 0,023 & 0,004 & 0,632 & 0,001 & 0,022 \\
\hline $\mathbf{1 7}$ & 0,025 & 0,024 & 0,001 & 0,140 & 0,000 & 0,023 \\
\hline $\mathbf{1 8}$ & 0,023 & 0,025 & 0,001 & 0,138 & 0,000 & 0,022 \\
\hline $\mathbf{1 9}$ & 0,022 & 0,018 & 0,005 & 0,874 & 0,001 & 0,026 \\
\hline $\mathbf{2 0}$ & 0,021 & 0,024 & 0,002 & 0,434 & 0,000 & 0,024 \\
\hline $\mathbf{2 1}$ & 0,020 & 0,017 & 0,003 & 0,671 & 0,001 & 0,027 \\
\hline $\mathbf{2 2}$ & 0,019 & 0,019 & 0,001 & 0,022 & 0,000 & 0,028 \\
\hline $\mathbf{2 3}$ & 0,018 & 0,017 & 0,002 & 0,294 & 0,000 & 0,029 \\
\hline $\mathbf{2 4}$ & 0,018 & 0,024 & 0,006 & 1,309 & 0,002 & 0,024 \\
\hline $\mathbf{2 5}$ & 0,017 & 0,019 & 0,002 & 0,294 & 0,000 & 0,022 \\
\hline $\mathbf{2 6}$ & 0,016 & 0,027 & 0,010 & 2,438 & 0,006 & 0,012 \\
\hline $\mathbf{2 7}$ & 0,016 & 0,017 & 0,001 & 0,118 & 0,000 & 0,011 \\
\hline $\mathbf{2 8}$ & 0,015 & 0,018 & 0,002 & 0,520 & 0,000 & 0,008 \\
\hline $\mathbf{2 9}$ & 0,015 & 0,017 & 0,002 & 0,405 & 0,000 & 0,006 \\
\hline
\end{tabular}




\begin{tabular}{|c|c|c|c|c|c|c|}
\hline & Benford & Svi prihodi & \multicolumn{4}{|c|}{ Svi prihodi } \\
\hline \# & Prva i druga & Prva i druga & MAD & $\mathrm{Z}$ test & Hi kvadrat & $\mathrm{K}-\mathrm{S}$ \\
\hline 30 & 0,014 & 0,018 & 0,003 & 0,807 & 0,001 & 0,003 \\
\hline 31 & 0,014 & 0,018 & 0,004 & 0,943 & 0,001 & 0,001 \\
\hline 32 & 0,013 & 0,006 & 0,007 & 1,931 & 0,004 & 0,006 \\
\hline 33 & 0,013 & 0,010 & 0,003 & 0,738 & 0,001 & 0,009 \\
\hline 34 & 0,013 & 0,007 & 0,006 & 1,486 & 0,003 & 0,015 \\
\hline 35 & 0,012 & 0,012 & 0,000 & 0,119 & 0,000 & 0,015 \\
\hline 36 & 0,012 & 0,009 & 0,003 & 0,746 & 0,001 & 0,018 \\
\hline 37 & 0,012 & 0,015 & 0,003 & 0,805 & 0,001 & 0,015 \\
\hline 38 & 0,011 & 0,010 & 0,001 & 0,282 & 0,000 & 0,017 \\
\hline 39 & 0,011 & 0,009 & 0,002 & 0,500 & 0,000 & 0,019 \\
\hline 40 & 0,011 & 0,007 & 0,004 & 1,031 & 0,001 & 0,023 \\
\hline 41 & 0,010 & 0,006 & 0,005 & 1,272 & 0,002 & 0,027 \\
\hline 42 & 0,010 & 0,008 & 0,002 & 0,584 & 0,001 & 0,030 \\
\hline 43 & 0,010 & 0,012 & 0,002 & 0,431 & 0,000 & 0,028 \\
\hline 44 & 0,010 & 0,006 & 0,004 & 1,088 & 0,002 & 0,032 \\
\hline 45 & 0,010 & 0,007 & 0,003 & 0,706 & 0,001 & 0,034 \\
\hline 46 & 0,009 & 0,012 & 0,002 & 0,659 & 0,001 & 0,032 \\
\hline 47 & 0,009 & 0,006 & 0,003 & 0,917 & 0,001 & 0,035 \\
\hline 48 & 0,009 & 0,006 & 0,003 & 0,863 & 0,001 & 0,038 \\
\hline 49 & 0,009 & 0,011 & 0,002 & 0,537 & 0,000 & 0,036 \\
\hline 50 & 0,009 & 0,011 & 0,002 & 0,602 & 0,001 & 0,034 \\
\hline 51 & 0,008 & 0,012 & 0,003 & 1,009 & 0,001 & 0,030 \\
\hline 52 & 0,008 & 0,011 & 0,003 & 0,729 & 0,001 & 0,028 \\
\hline 53 & 0,008 & 0,007 & 0,001 & 0,259 & 0,000 & 0,029 \\
\hline 54 & 0,008 & 0,011 & 0,003 & 0,851 & 0,001 & 0,026 \\
\hline 55 & 0,008 & 0,007 & 0,001 & 0,158 & 0,000 & 0,027 \\
\hline 56 & 0,008 & 0,006 & 0,002 & 0,468 & 0,000 & 0,029 \\
\hline 57 & 0,008 & 0,007 & 0,001 & 0,060 & 0,000 & 0,029 \\
\hline 58 & 0,007 & 0,015 & 0,007 & 2,547 & 0,007 & 0,022 \\
\hline 59 & 0,007 & 0,008 & 0,001 & 0,034 & 0,000 & 0,022 \\
\hline 60 & 0,007 & 0,009 & 0,002 & 0,451 & 0,000 & 0,020 \\
\hline 61 & 0,007 & 0,011 & 0,004 & 1,249 & 0,002 & 0,016 \\
\hline 62 & 0,007 & 0,006 & 0,001 & 0,209 & 0,000 & 0,017 \\
\hline 63 & 0,007 & 0,009 & 0,002 & 0,593 & 0,001 & 0,015 \\
\hline 64 & 0,007 & 0,006 & 0,001 & 0,128 & 0,000 & 0,016 \\
\hline 65 & 0,007 & 0,008 & 0,001 & 0,298 & 0,000 & 0,015 \\
\hline 66 & 0,007 & 0,009 & 0,002 & 0,729 & 0,001 & 0,012 \\
\hline 67 & 0,006 & 0,007 & 0,000 & 0,184 & 0,000 & 0,012 \\
\hline 68 & 0,006 & 0,006 & 0,000 & 0,172 & 0,000 & 0,012 \\
\hline
\end{tabular}




\begin{tabular}{|c|c|c|c|c|c|c|}
\hline & Benford & Svi prihodi & & Svi & hodi & \\
\hline$\#$ & Prva i druga & Prva i druga & MAD & $\mathrm{Z}$ test & Hi kvadrat & $\mathrm{K}-\mathrm{S}$ \\
\hline 69 & 0,006 & 0,008 & 0,002 & 0,461 & 0,000 & 0,011 \\
\hline 70 & 0,006 & 0,007 & 0,001 & 0,099 & 0,000 & 0,010 \\
\hline 71 & 0,006 & 0,006 & 0,000 & 0,067 & 0,000 & 0,010 \\
\hline 72 & 0,006 & 0,004 & 0,002 & 0,643 & 0,001 & 0,012 \\
\hline 73 & 0,006 & 0,008 & 0,002 & 0,615 & 0,001 & 0,010 \\
\hline 74 & 0,006 & 0,002 & 0,004 & 1,409 & 0,003 & 0,014 \\
\hline 75 & 0,006 & 0,004 & 0,002 & 0,556 & 0,001 & 0,016 \\
\hline 76 & 0,006 & 0,005 & 0,001 & 0,110 & 0,000 & 0,017 \\
\hline 77 & 0,006 & 0,005 & 0,001 & 0,079 & 0,000 & 0,017 \\
\hline 78 & 0,006 & 0,008 & 0,002 & 0,797 & 0,001 & 0,015 \\
\hline 79 & 0,005 & 0,008 & 0,002 & 0,833 & 0,001 & 0,012 \\
\hline 80 & 0,005 & 0,009 & 0,003 & 1,296 & 0,002 & 0,009 \\
\hline 81 & 0,005 & 0,009 & 0,004 & 1,333 & 0,002 & 0,005 \\
\hline 82 & 0,005 & 0,003 & 0,002 & 0,800 & 0,001 & 0,008 \\
\hline 83 & 0,005 & 0,005 & 0,000 & 0,122 & 0,000 & 0,008 \\
\hline 84 & 0,005 & 0,012 & 0,007 & 2,758 & 0,009 & 0,001 \\
\hline 85 & 0,005 & 0,004 & 0,001 & 0,290 & 0,000 & 0,002 \\
\hline 86 & 0,005 & 0,005 & 0,000 & 0,043 & 0,000 & 0,003 \\
\hline 87 & 0,005 & 0,005 & 0,000 & 0,017 & 0,000 & 0,003 \\
\hline 88 & 0,005 & 0,009 & 0,004 & 1,581 & 0,003 & 0,001 \\
\hline 89 & 0,005 & 0,007 & 0,002 & 0,711 & 0,001 & 0,003 \\
\hline 90 & 0,005 & 0,003 & 0,002 & 0,623 & 0,001 & 0,002 \\
\hline 91 & 0,005 & 0,005 & 0,000 & 0,083 & 0,000 & 0,002 \\
\hline 92 & 0,005 & 0,001 & 0,004 & 1,499 & 0,003 & 0,002 \\
\hline 93 & 0,005 & 0,004 & 0,001 & 0,099 & 0,000 & 0,003 \\
\hline 94 & 0,005 & 0,006 & 0,001 & 0,388 & 0,000 & 0,001 \\
\hline 95 & 0,005 & 0,003 & 0,002 & 0,521 & 0,001 & 0,003 \\
\hline 96 & 0,005 & 0,006 & 0,001 & 0,437 & 0,000 & 0,002 \\
\hline 97 & 0,004 & 0,004 & 0,001 & 0,010 & 0,000 & 0,002 \\
\hline 98 & 0,004 & 0,008 & 0,003 & 1,433 & 0,003 & 0,001 \\
\hline \multirow[t]{2}{*}{99} & 0,004 & 0,003 & 0,001 & 0,443 & 0,000 & 0,000 \\
\hline & & & 0,003 & & 0,090 & 0,043 \\
\hline
\end{tabular}

Izvor: izrada autora. 